\title{
The Problem of Unobserved Anomalies
}

\author{
SEUNGBAE PARK \\ Ulsan National Institute of Science and Technology, 50, UNIST-gil, Eonyang-eup, Ulju-gun, Ulsan, South Korea \\ Email: nature@unist.ac.kr
}

\begin{abstract}
Scientific antirealism, the view that successful theories are empirically adequate, is untenable in light of the problem of unobserved anomalies that since past scientists could not observe the anomalies that caused the replacement of past theories with present theories, present scientists cannot observe the anomalies either that will cause the replacement of present theories with future theories. There are several moves that antirealists would be tempted to make to get around the problem of unobserved anomalies. All of them, however, are problematic.
\end{abstract}

Keywords: instrumentalism, pessimistic induction, scientific antirealism, unconceived alternatives, unobserved anomalies

\section{INTRODUCTION}

This paper defines scientific antirealism as the view that successful theories, such as the oxygen theory, the kinetic theory, the germ theory, and the special theory of relativity, are merely empirically adequate. I argue that antirealism cannot survive a pessimistic induction that I call the problem of unobserved anomalies ${ }^{1}$. It holds that since past scientists could not observe the anomalies that caused scientific revolutions, it is likely that present scientists cannot observe anomalies either that will cause scientific revolutions ${ }^{2}$. On this account, both past and present theories are empirically inadequate.

In this paper, 'pessimists' refer to those who embrace the problem of unobserved anomalies. Of course, they are different from other pessimists, such as P. K. Stanford (2006) and K. B. Wray (2013), in that the former attack antirealism whereas the latter attack realism. This paper unfolds a debate between antirealists and the former pessimists. Thus, antirealists' interlocutors in this paper are not realists but the pessimists who attack antirealism with the problem of unobserved anomalies. There are no realists in this paper. So in this paper, it is illegitimate for antirealists to challenge their interlocutors to defend realism from their objections.

This paper is radically different from other papers in the literature in that it focuses on whether antirealism is tenable or not vis-à-vis a pessimistic induction, whereas other papers tend to focus on whether realism is tenable or not vis-à-vis other pessimistic inductions. This paper is built upon the idea that antirealism, to be a viable contender to realism, should withstand criticisms similar to those levelled at realism, and on the observation that antirealists have not paid attention to the disconcerting issue that their criticisms against realism also apply to their position.

1 The phrase 'unobserved anomalies' originates from Park (2001: 32).

2 I drop 'likely' hereafter for the sake of convenience. 
The outline of this paper is as follows. In Section 2, I flesh out the problem of unobserved anomalies. In Section 3, I anticipate and criticize the following possible antirealist responses to it. First, scientific theories making novel predictions are empirically adequate. Second, pessimists should bear some burdens of proof. Third, successful theories are good instruments for making predictions. Fourth, antirealists are not committed to any positive position. Fifth, antirealists might hold a weaker position that it is better to believe that successful theories are empirically adequate than to believe that they are true. It will become clear that none of these responses is satisfactory.

\section{THE PROBLEM OF UNOBSERVED ANOMALIES}

B. van Fraassen (1985: 294) claims that successful theories are empirically adequate. Similarly, K. B. Wray says that "all that scientists can claim to know about their background theories is that they save the phenomena and are superior to the theories with which they were compared" (2008: 321). To say that a theory saves phenomena means that it is empirically adequate (van Fraassen 1980: 12). In another paper, Wray maintains that neither "realist nor anti-realist denies that the claims that successful scientific theories make about observable phenomena are true" (2012: 376). M. Alai interprets constructive empiricism as maintaining that "all we need to believe is that a theory is empirically adequate" (2017:21). Thus, van Fraassen, Wray, and Alai would agree with the present definition of antirealism that successful theories are empirically adequate.

Are we justified in believing that successful theories are empirically adequate? Three philosophers (Park 2001: 78; Lange 2002: 282; Lyons 2003: 898) say no, running a pessimistic induction against antirealism. It holds that since past theories, such as the phlogiston theory, the caloric theory, and Newtonian mechanics, were empirically inadequate, present theories, such as the oxygen theory, the kinetic theory, and the theory of relativity, are also empirically inadequate. Present theories may appear to be empirically adequate, but they will turn out to be empirically inadequate, just as past theories did.

Past theories turned out to be empirically inadequate via running into anomalies, i.e. via clashing with phenomena that they could not explain. The anomalies, however, were not observed by proponents of past theories, although they fell within the domains of past theories. They were later observed by subsequent scientists, and then triggered scientific revolutions. For example, the perihelion motion of Mercury was not observed by Newton, although it fell within the domain of Newtonian mechanics. It was later observed and led to the replacement of Newtonian mechanics with Einsteinian mechanics. It was an unobserved anomaly to Newtonian mechanics.

Now that the concept of an unobserved anomaly is clear, we are ready to formulate the problem of unobserved anomalies: since past scientists could not observe the anomalies that caused the replacement of their theories with present theories, present scientists cannot observe the anomalies either that will cause the replacement of present theories with future theories. Future scientists will be able to observe the anomalies to present theories, just as present scientists can observe the anomalies to past theories. Present theories may appear to be empirically adequate, but future data will reveal that they are empirically inadequate. It is not merely possible but likely that present theories will go the way of past theories.

The problem of unobserved anomalies combines the aforementioned three philosophers' pessimistic induction against antirealism with Thomas Kuhn's view (1962/1970) on the causes of scientific revolutions that a scientific revolution is caused by the accumulation of serious anomaliesand by the advent of a new paradigm. In the absence of either, a scientific upheaval cannot occur. The pessimistic induction against antirealism and Kuhn's view jointly imply that present theories will run into hitherto unobserved anomalies, just as past theories ran into 
anomalies that had previously been unobserved, and that, as a result, present theories will be superseded by future theories, just as past theories have been superseded by present theories.

The problem of unobserved anomalies consists of the premise that past scientists could not observe the anomalies to past theories, and the conclusion that present scientists cannot observe the anomalies to present theories. The premise can be justified by Stanford's long list of transitions from past to present theories:

Stanford's List

from elemental to early corpuscularian chemistry to Stahl's phlogiston theory to Lavoisier's oxygen chemistry to Daltonian atomic and contemporary chemistry

from various versions of preformationism to epigenetic theories of embryology

from the caloric theory of heat to later and ultimately contemporary thermodynamic theories from effluvial theories of electricity and magnetism to theories of the electromagnetic ether and contemporary electromagnetism

from humoral imbalance to miasmatic to contagion and ultimately germ theories of disease from eighteenth century corpuscular theories of light to nineteenth century wave theories to the contemporary quantum mechanical conception

from Darwin's pangenesis theory of inheritance to Weismann's germ-plasm theory to Mendelian and then contemporary molecular genetics

from Cuvier's theory of functionally integrated and necessarily static biological species and from Lamarck's autogenesis to Darwin's evolutionary theory (Stanford 2006: 19-20).

This list is intended to support the premise that past scientists could not conceive of present theories. The premise allegedly supports the conclusion that present scientists cannot conceive of future theories. The premise and the conclusion jointly comprise what is called the problem of unconceived alternatives.

The problem of unobserved anomalies mirrors the problem of unconceived alternatives. If Stanford's list supports the premise of the problem of unconceived alternatives, it also supports the premise of the problem of unobserved anomalies. There is no reason for thinking that it supports the former while it does not support the latter. Also, if the inference from the premise to the conclusion of the problem of unconceived alternatives is correct, the inference from the premise to the conclusion of the problem of unobserved anomalies is also correct. There is no reason for thinking that the former is correct while the latter is incorrect. So the problems of unobserved anomalies and unconceived alternatives enjoy the same inductive strength. There is a further similarity between them, viz., they both appeal to items that are initially not brought to scientists' consciousness, but are later brought to their consciousness, and bring about scientific revolutions.

There is a difference between the problems of unobserved anomalies and unconceived alternatives. As noted earlier, the problem of unobserved anomalies combines the pessimistic induction against antirealism with Kuhn's view on the causes of scientific revolutions, whereas the problem of unconceived alternatives combines the pessimistic induction against realism with the problem of underdetermination. The pessimistic induction against realism holds that since past theories turned out to be false, present theories will also turn out to be false (Poincaré 1905/1952: 160; Mach 1911: 17; Laudan 1977: 126; Putnam 1978: 25). The problem of underdetermination occurs when theories make different claims about unobservables but similar claims about observables. Thus, the problem of unobserved anomalies is levelled at antirealism, whereas the problem of unconceived alternatives is levelled at realism. 
In this section, I argued that the problem of unconceived anomalies poses a threat to antirealism. In the next section, I anticipate and rebut several possible antirealist responses to the problem of unobserved anomalies.

\section{ANTIREALIST RESPONSES AND THEIR PROBLEMS Novel Prediction}

To avoid the problem of unobserved anomalies, antirealists might tap into J. Saatsi's critical response to the problem of unconceived alternatives. He contends that "the instances of unconceived underdetermination cited by Stanford by and large do not involve any novel predictive success" (2009: 358). Saatsi's hope is that once realists believe that only those theories which make novel predictions are approximately true, they do not have to worry about the past theories on Stanford's list because they did not make novel predictions. Utilizing Saatsi's insight, antirealists might suggest that we were not justified in believing that past theories on Stanford's list were empirically adequate, given that they did not make novel predictions, but we are justified in believing that present theories are empirically adequate, given that they make novel predictions. In other words, novel success reliably indicates empirical adequacy, although mere success does not.

This move, however, is problematic in light of Stanford's and T. Lyons's replies to Saatsi's move. Stanford objects that some past theories, for example, Fresnel's wave theory of light, did make novel predictions (2009: 384). Lyons (2003: 898-899) puts forward a list of many past theories, such as the caloric theory, the phlogiston theory, and Dalton's atomic theory, which, he claims, made novel predictions, and yet were false in the present light. Stanford's and Lyons's historical observations imply that even if antirealists raise their bar from success to novel success, antirealism is still vulnerable to the problem of unobserved anomalies.

\section{Creating Burdens of Proof}

Antirealists might seek a strategy of creating burdens of proof for pessimists. Different burdens of proof would arise, depending on whether there are finitely or infinitely many unconceived alternatives in the possibility space of unconceived alternatives. Stanford (2006: 133) claims that the number of unconceived alternatives is infinite, whereas S. Ruhmkorff (2011) claims that it is finite. Instead of adjudicating between them, I explore different burdens of proof that would arise in either case. In the end, however, under either assumption, the profferred antirealist strategy to tackle the problem of unobserved anomalies will be shown to be ineffective.

Suppose first that there are a finite number of unconceived alternatives. Under this assumption, antirealists can argue that as Stanford's long list shows, we have already discarded enough alternatives having unobserved anomalies, and we are now at the end of the finitely long chains of alternatives in the possibility space, i.e. current theories are free of unobserved anomalies. By contrast, pessimists can argue that we have not yet eliminated enough theories, and need to discard more before we reach unconceived alternatives which are free of unobserved anomalies. For example, the humoral theory and the miasma theory have been eliminated, and the germ theory is accepted today. Suppose that these are the only theories of diseases in the possibility space of alternatives. In such a case, we have already eliminated enough alternatives having unobserved anomalies, so we can conclude that the germ theory does not have an unobserved anomaly. Suppose now that there are one million theories of diseases in the possibility space. In such a case, we have not yet eliminated enough alternatives having unobserved anomalies, so the germ theory has an unobserved anomaly. 
We do not know how large the finite number of theories of diseases is. Consequently, antirealists would challenge pessimists to present reasons for thinking that the pessimist belief that we have not yet eliminated enough theories is more likely to be true than the antirealist belief that we have already eliminated enough theories. Without such reasons, the problem of unobserved anomalies does not go through. Pessimists, however, would challenge antirealists to present reasons for thinking that the antirealist belief that we have already discarded enough alternatives is more likely to be true than the pessimist belief that we have not yet discarded enough theories. Without such reasons, we are not justified in believing that present theories are empirically adequate, and hence antirealism is not tenable. Thus, pessimists and antirealists have reached a stalemate.

Suppose instead that there are an infinite number of unconceived alternatives. Pessimists would have a strong case against antirealism under this assumption. If there were infinitely many unconceived alternatives, unobserved anomalies would plague our theories indefinitely into the future. Theories free of unobserved anomalies would lie at the infinitely distant points of the infinitely long chains of unconceived alternatives. Since we are finite beings, we can only eliminate finitely many alternatives, and will never be able to reach points at which theories are free of unobserved anomalies.

How could antirealists respond to this case? They could point out that the number of empirically adequate rivals can be infinite, appealing to van Fraassen's famous example of the problem of underdetermination (1980: 46). He generates an infinite number of rival theories to Newtonian mechanics by varying the velocity of the solar system with respect to the absolute space. All the competitors share the three laws of motion and the law of gravity, but they do not share claims about the absolute velocity of the universe. If one of these competitors is true, then all of them would be empirically adequate. Thus, there can be infinitely many empirically adequate rivals, and such theories are all free of unobserved anomalies.

How does van Fraassen's example help antirealism? Antirealists can argue that unconceived alternatives, which are free of unobserved anomalies, take up an infinitely large portion of the infinitely long chain of unconceived alternatives, and that the set of such theories might include current theories. The problem of unobserved anomalies, however, requires the opposite assumption that the set does not include current theories. Consequently, pessimists have the burden to present reasons for thinking that their belief that the set does not include current theories is more likely to be true than the antirealist belief that the set does include current theories. In the absence of such reasons, the problem of unobserved anomalies does not go through.

The observation that empirically adequate rivals can be infinitely many, however, cannot give antirealists what they need because empirically inadequate rivals can also be infinitely many. Given that Newtonian mechanics is empirically inadequate, van Fraassen's example shows not only that there can be infinitely many empirically adequate rivals but also that there can be infinitely many empirically inadequate rivals. There is no reason for thinking that present theories are more likely to belong to the set of infinitely many empirically adequate theories than to the set of infinitely many empirically inadequate theories. Thus, we are back to a stalemate between antirealists and pessimists.

To summarize, it does not matter whether the number of unconceived alternatives is finite or infinite. It is up for grabs whether current theories are more or less likely to lie in the range of infinitely many empirically adequate rivals than in the range of infinitely many empirically inadequate rivals. Hence, we are not justified in believing that present theories are empirically adequate. 


\section{Instrumentalism}

Stanford, a leading philosopher of science in the realism debate these days, embraces a positive position called epistemic instrumentalism. He defines it as follows:

what it means to be an instrumentalist about any particular theory is to believe the empirical predictions and recipes for intervention that the theory offers, but not the description of some part of nature in which those pragmatic recommendations are grounded (Stanford 2006: 195).

To put it another way, instrumentalists believe that predictions of a successful theory are true, and use the theory to manipulate things, but do not believe that what it says about unobservables is true. It is not clear whether instrumentalists believe that all the predictions of a theory are true, and whether all the recipes derived from a theory are useful. So instrumentalism seems to be neutral as to whether successful theories are empirically adequate or less than empirically adequate. It appears, therefore, that the problem of unobserved anomalies does not spell doom for instrumentalism.

On closer examination, however, the problem of unobserved anomalies does pose a threat to instrumentalism. It is not clear whether instrumentalists are justified in believing that present theories are good instruments for making predictions and for deriving recipes for intervention. Instrumentalists might contend that present theories are good instruments. Pessimists would, however, object that present theories are fated to be displaced by their successors due to unobserved anomalies. Such a consideration gives rise to the suspicion that they are bad instruments, although they now appear to be good instruments. Moreover, we do not believe today that past theories, such as the caloric theory and the ether theory, are good instruments, although our ancestors believed that they were. Similarly, although we believe now that present theories are good instruments, our descendants will not.

Instrumentalists might reply that past theories are still good instruments, for we can still use them to make true predictions in certain domains. For example, we still use Newtonian mechanics to send a rocket to the moon. Since past theories are still good instruments, present theories will be good instruments for our descendents. As science progresses, our theories will be closer and closer to ideal usefulness. Present theories are closer to ideal usefulness than past theories. Analogously, future theories will be even closer to ideal usefulness than present theories. All of them are good instruments.

A problem with this position is that present theories are fated to run into anomalies, just as past theories were, and hence we should worry that they might not work when they are applied to new phenomena despite the fact that the new phenomena belong to their domains. Can we call such theories good instruments? Pessimists might define 'a good instrument' as an instrument that works well even when it is applied to new phenomena in its domain, and then claim that present theories fall short of good instruments. Instrumentalists might retort that they are good instruments insofar as they work well when they are applied to old phenomena in their domains. Let me point out here that this dispute between pessimists and instrumentalists is merely terminological. That is, while instrumentalists are willing to ascribe 'good instruments' to past and present theories, pessimists are not. In such a dispute, it is merely a matter of taste whether to attribute 'good instruments' to past and present theories ${ }^{3}$.

My critical response to instrumentalism here echoes Stanford's (2015) critical response to selectivism. S. Psillos (1999: 127) claims that past theories were approximately true on the grounds that their working posits were true, although their idle posits were false. Stanford replies that

\footnotetext{
3 See Park (2015, 2016, 2017, Forthcoming) for more criticisms against instrumentalism.
} 
the difference between pessimists and selectivists "is simply a difference of style or taste in applying the expression 'approximately true' rather than a substantive disagreement between them" (2015: 876). On his account, there is no fact of the matter as to whether to apply approximately true' to successful theories or not. I say the same thing about the difference between instrumentalists who attribute 'good instruments' to successful theories and pessimists who refuse do so.

Antirealists might raise the following objection. Should we regard science now as utterly pointless? Should we have no confidence at all in its predictions about the future? An idea that leads to skepticism is absurd. As some philosophers put it, "Skepticism is an ugly threat; a philosophical position which leads to skepticism reduces itself to absurdity" (Ladyman et al. 1997: 317). The problem of unobserved anomalies prohibits us from even believing that successful theories are good instruments. Therefore, it is an absurd idea.

Consider, however, that the problem of unobserved anomalies parallels the problem of unconceived alternatives. So if the former is absurd, the latter is also absurd. In order to avoid this criticism against the latter, Stanford would have to expose a relevant difference between the two problems that would entitle him to say that the problem of unobserved anomalies drives us to skepticism but the problem of unconceived alternatives does not. It is not clear to me what the relevant difference would be.

\section{Noncommittalism}

Antirealists might despair and adopt a new position that might be called noncommittalism. It is the position that is not committed to any claim. It is committed neither to the claim that successful theories are empirically adequate, nor to the claim that they are good instruments. So it is immune to the problem of unconceived anomalies. Nor is it committed to the claim that Cartesian skepticism is committed to, viz., the claim that we do not know anything about the world. So it is insusceptible to all the criticisms levelled at the Cartesian skepticism. Noncommittalism is a perfect position in terms of its defensibility. It withstands any criticism because it is not committed to any claim that you think that it is committed to. It is natural, therefore, that noncommittalism gets around the problem of unobserved anomalies.

There is, however, an epistemic disadvantage with noncommittalism. Noncommittalists ought to be noncommittal even about their own positive theories. Imagine that they worked day and night for several decades in their laboratories, and finally came up with a scientific theory. It has all the theoretical virtues, such as a broad scope, accuracy, simplicity, and fruitfulness. The noncommittalists are so excited about their theory that they believe that it is true. They, however, ought not to believe that it is true. Nor ought they to even believe that it is empirically adequate. They simply ought to be noncommittal about it in accordance with noncommittalism.

There is another epistemic disadvantage with noncommittalism. Noncommittalists should not have a problem with their epistemic colleagues who are noncommittal about their positive scientific theory. Their colleagues do not even believe that it is empirically adequate. If all of us were noncommittalists, none of us would be able to propagate to others our own theories which we are confident about. So what? We have not only the epistemic goal to be safe when our epistemic colleagues advance their positive theories but also the epistemic goal to spread our positive theories to them (Park 2017: 58). Noncommittalism is a useful epistemic policy to achieve the first goal, but not the second goal.

The failure to achieve the second goal is accompanied by enormous practical disadvantages. Imagine that noncommittalists submit an application to the Norwegian Novel Committee for a Nobel Prize. To their disappointment, however, the committee does not even believe that their theory is a good instrument, and hence refuses to grant a Nobel Prize to the non- 
committalists. The noncommittalists protest that their theory is so virtuous that the committee should believe that it is true or empirically adequate. The committee retorts that it is a double standard for the noncommittalists to expect that the committee would believe that it is true or empirically adequate.

In sum, if you embrace noncommittalism, you can get around the problem of unconceived anomalies, but epistemic and practical disadvantages with it are so ponderous that you would not actually hold it in your daily life. You may hold it only for philosophical fun. Even from a philosophical perspective, it is hardly an impressive position. No mental energy is required to hold it. Brilliant antirealists would face the problem of unobserved anomalies head-on, and attempt to refute it instead of abandoning their position and embracing noncommittalism. In any event, pessimists' interlocutors in this paper are not noncommittalists but antirealists, and antirealists should not be confounded with noncommittalists.

\section{Weaker Position}

Antirealists might retreat to a weaker position that it is better to believe that successful theories are empirically adequate than to believe that they are true. This position is committed neither to the view that successful theories are empirically adequate nor to the view that they are good instruments. So it does not fall prey to the problem of unobserved anomalies.

This antirealist position, however, is so weak that it is vulnerable to the criticisms that I launched at noncommittalism above. Imagine again that antirealists developed a scientific theory. It is so virtuous that they believe that it is true or empirically adequate. They, however, should not even believe that it is a good instrument. They can only believe that it is better to believe that it is empirically adequate than to believe that it is true. Now, they submit an application to the Norwegian Novel Committee for a Novel Prize. To their dismay, however, the committee rejects their application, saying that they do not even believe that the antirealists' theory is a good instrument, and that a scientific theory should be a good instrument to be worthy of consideration for a Nobel Prize. To be fair, the committee adds that although they do not believe that it is a good instrument, they believe that it is better to believe that it is empirically adequate than to believe that it is true.

\section{CONCLUSIONS}

The problem of unobserved anomalies parallels Stanford's problem of unconceived alternatives. The two problems, however, are aimed at different targets. The former is levelled at antirealism, and the latter at realism. A moral from the problem of unobserved anomalies is that antirealists should be careful when they mount a criticism against realism. Otherwise, they may unwittingly set their own house on fire.

Let me remind readers that the opposing interlocutors in this paper are antirealists who believe that successful theories are empirically adequate, and pessimists who believe that successful theories are empirically inadequate due to the problem of unobserved anomalies. They are not joined by realists who believe that successful theories are true. Brilliant antirealists would attempt to defend antirealism from the problem of unobserved anomalies instead of requesting realists to defend realism from the problem of unobserved anomalies.

\section{ACKNOWLEDGEMENTS}

This work was supported by the Ministry of Education of the Republic of Korea and the National Research Foundation of Korea (NRF-2016S1A5A2A01022592). 


\title{
References
}

1. Alai, M. 2017. "The Debates on Scientific Realism Today: Knowledge and Objectivity in Science", in Varieties of Scientific Realism: Objectivity and Truth in Science, ed. E. Agazzi. Switzerland: Springer International Publishing, 19-47.

2. Kuhn, T. 1962/1970. The Structure of Scientific Revolutions. Chicago: University of Chicago Press.

3. Ladyman, J.; Douven, I.; Horsten, L.; van Fraassen, B. 1997. "A Defense of van Fraassen's Critique of Abductive Inference: Reply to Psillos", The Philosophical Quarterly 47(188): 305-321.

4. Lange, M. 2002. "Baseball, Pessimistic Inductions and the Turnover Fallacy", Analysis 62(4): 2881-2885.

5. Laudan, L. 1977. Progress and Its Problems: Towards a Theory of Scientific Growth. California: University of California Press.

6. Lyons, T. 2003. "Explaining the Success of a Scientific Theory", Philosophy of Science 70(5): 891-901.

7. Mach, E. 1911. History and Root of the Principle of the Conservation of Energy. Translated by P. E. B. Jourdain. Chicago: Open Court Publishing Company.

8. Park, S. 2001. Scientific Realism vs. Scientific Antirealism. Ph. D. Dissertation. University of Arizona.

9. Park, S. 2015. “Accepting Our Best Scientific Theories", Filosofija. Sociologija 26(3): 218-227.

10. Park, S. 2016. "Scientific Realism and Antirealism in Science Education", Coactivity: Philosophy. Communication 24(1): 72-81.

11. Park, S. 2017. "Defense of Epistemic Reciprocalism", Filosofija. Sociologija 28(1): 56-64.

12. Park, S. Forthcoming. "Should Scientists Embrance Scientific Realism or Antirealism", The Philosophical Forum.

13. Poincaré, H. 1905/1952. Science and Hypothesis. New York: Dover.

14. Psillos, S. 1999. Scientific Realism: How Science Tracks Truth. New York: Routledge.

15. Putnam, H. 1978. Meaning and the Moral Sciences. London: Routledge \& K. Paul.

16. Ruhmkorff, S. 2011. "Some Difficulties for the Problem of Unconceived Alternatives", Philosophy of Science 78(5): 875-886.

17. Saatsi, J. 2009. "Grasping at Realist Straws", Metascience 18: 379-390.

18. Stanford, P. K. 2006. Exceeding Our Grasp: Science, History, and the Problem of Unconceived Alternatives. Oxford: Oxford University Press.

19. Stanford, P. K. 2015. "Catastrophism, Uniformitarianism, and a Scientific Realism Debate That Makes a Difference", Philosophy of Science 82(5): 867-878.

20. Van Fraassen, B. C. 1980. The Scientific Image. Oxford: Oxford University Press.

21. Van Fraassen, B. C. 1985. "Empiricism in the Philosophy of Science", in Images of Science, eds. P. Churchland and C. Hooker. Chicago: University of Chicago Press.

22. Wray, K. B. 2008. "The Argument from Underconsideration as Grounds for Anti-Realism: A Defence", International Studies in the Philosophy of Science 22(3): 317-326.

23. Wray, K. B. 2012. "Epistemic Privilege and the Success of Science", Noûs 46(3): 375-385.

24. Wray, K. B. 2013. "Pessimistic Induction and the Exponential Growth of Science Reassessed", Synthese 190(18): 4321-4330.

\section{SEUNGBAE PARK}

\section{Nestebimų anomalijų problema}

\begin{abstract}
Santrauka
Mokslinis antirealizmas (požiūris, kad sèkmingos teorijos yra empiriškai adekvačios) yra nepriimtinas atsižvelgiant ị nestebimų anomalijų problemą - kad ankstesni mokslininkai neturèjo galimybès stebèti anomalijų, kurios buvo senųų teorijų pakeitimo dabartinèmis priežastis, o dabarties mokslininkai taip pat neturi galimybès stebèti anomalijų, kurios bus dabartinių teorijų pakeitimo vėlesnèmis priežastis. Yra keletas sprendimų, kurie antirealistams, siekiantiems kovoti su nestebimų anomalijų problema, būtų patrauklūs. Tačiau visi sprendimai patys yra problemiški.
\end{abstract}

Raktažodžiai: instrumentalizmas, mokslinis antirealizmas, nesuvoktos alternatyvos, nestebimos anomalijos, pesimistinè indukcija 